\title{
Burundi and Gambia: Regional Security and Rapid Deployment Capability. The Utility of the African Standby Force
}

\author{
Enoch Ndem OKON \\ Dodeye Uduak WILLIAMS
}

\begin{abstract}
The paper evaluates the Rapid Deployment Capability (RDC) of the African Standby Force (ASF) in post - Road Map III after 2015, viz-a-viz its' mandate as the mechanism for regional Peace Support Operations (PSOs). The ASF failed to respond timeously to Malian and Central African Republic (CAR) conflicts in 2013 and this led to the formation of African Capacity for Immediate Response to Crises (ACIRC) as an interim RDC mechanism till 2015. The study is grounded on the theory of Collective Security. It adopts Case Study Research Design. Data are generated from both primary and secondary sources. Primary data are generated from Open-end interview, using purpose sampling method and secondary data involve the review of extant literature. Data are presented qualitatively on tables and analysed, using Content Analysis techniques. The study discusses the uniformity and differences in the generation of the ASF'S RDC in the management of Burundian and Gambian conflicts of 2015 and 2017 respectively. It reveals the factors which led to these differences in outcome, specifically the role of
\end{abstract} 'democratic density' and 'competitive democratic security community' and their impacts on conflict resolution in Africa. The study concludes that the $R D C$ of the ASF is needed for robust regional security in Africa and recommends pragmatic and sustainable funding of the mechanism, as well as the creation of 'security communities' through shared democratic values across the continent.

Keywords: Regional Security, African Standby Force, Rapid Deployment Capability, Burundi, The Gambia.

\section{Introduction}

Enoch Ndem OKON

Department of Political Science

University of Calabar, Nigeria

E-mail: enochokon@gmail.com

Dodeye Uduak WILLIAMS

Department of Political Science

University of Calabar, Nigeria

E-mail: williamsdodeye@yahoo.com

Conflict Studies Quarterly

Issue 24, July 2018, pp. 44-70

The last few decades have shown major DOI:10.24193/csq.24.4

changes in the approach to regional secu-

Published First Online: 05/07/2018 
rity which favor the formation and deployment of regional mechanisms with Rapid Deployment Capability (RDC) for Peace Support Operations (PSOs) across the world. This is illustrated by the establishment of numerous regional RDC mechanisms such as Nordic Coordinated Arrangement for Military Peace Support (NORDICAPS) in 1997, South East Europe Multinational Brigade (SEEBRIG) in 2002, NATO Response Force (NRF) in 2002, European Union Battlegroup (EUBG) in 2003, the African Standby Force (ASF) in 2003, the Combined Joint Expeditionary Force (CJEF) in 2010, and Joint Expeditionary Force (JEF) in 2014 among others (Hendriks, 2014; Kaitera \& Ben-Ari, 2008; Kasumba \& Debrah, 2010; Saxi, 2011; Tagarev, 2003). This is remarkable given these regional organizations' willingness to intervene in order to prevent or contain civil wars and the inherent harmful spillover (Tavares, 2010). Specifically, between 1990 and 2016, Africa has witnessed several coalitions, ranging from ECOWAS Monitoring Group (ECOMOG) to SADC African Brigade (SADCBRIG) which has delivered some level of stability in their various sub-regions (Essuman-Johnson, 2009). This development can be traced to the unwillingness of the United Nations (UN) and Western countries to intervene in theatres of conflict in post-Cold War Africa. For instance, the United States refused to intervene in the Liberia and Britain in Sierra Leone Crises, respectively, despite their historic and cultural affinities.

In these scenarios, Nigeria led sub-regional Rapid Deployment Capacity (RDC) mechanism - ECOWAS Monitoring Group (ECOMOG) salvaged the humanitarian disasters which were unfolding (Okoro, 2002; Ali, 2012). In similar scenarios in the Horn of Africa and the Great Lakes regions where there was no such RDC mechanism as in West Africa, the humanitarian disaster,such as mass killing, massive refugee flow and genocide, were obvious (Checha, 2004; Kalyvas, 2001; Mengisteab, 2011; Williams, 2011; Reid, 2014). Evidently, the absence of sub-regional RDC mechanisms contributed to the Rwandan genocide and left Somalia as a failed state after the fall of General Said Barre from 1991 (Fearon \& Laitin, 2003; Prunier, 1995). Similarly, DRCongo and the surrounding the Great Lakes are still engaged in conflict even two decades after the exit of late President Mobutu Sese Seko (Cleaver \& Massey, 2001). Besides, Sudan witnessed ethnic cleansing under President Al Bashir in Darfur, which was checked by the AU intervention (Franke, 2006). Instructively, these internal conflicts were rooted in democratic deficits, ethnoregional diversity, political identity, income inequality, internal colonialism and state failure, among other factors which are within the purview of the states (Kaldor, 2007; Koops, 2009; Newman, 2004; Tatschl, 2009). However, the domino effects of these conflicts were felt by neighboring countries and, therefore, revealed the 'regional security complexes', since 'failed states' do not only dislocate and destroy their own citizens, but also threaten their neighbors through refugee flow, political instability and random warfare (Buzan, 1991; Helman\& Ratner, 1993).

These experiences further stimulate the desire of African regional organizations to strengthen their organizational structures and processes and, indeed, their RDC mecha- 
nisms in order to respond to these violent conflicts in line with the provision of Articles 43 and 13 of the UN Charter and AUPeace and Security Protocol respectively (African Union, 2002; Bah, Choge-Nyangoro, Dersso, Mofya, \& Murithi, 2014; Knight, 1996; Greenhill, 2001). In spite of these efforts, some scholars question the desirability of regional RDC in Africa and therefore call for its disbandment (Dorn, 1998; Cocodia, 2016). This paper, therefore, focuses on the utility of regional RDC in the management of conflicts in Burundi and The Gambia between 2015 and 2017 and sets to answer two inter related questions, namely:

1. Was regional RDC needed for intervention in the Burundian and Gambian conflicts of 2015 and 2017 ?

2. What was responsible for disparity in generating regional RDC in the Burundian and Gambian conflicts?

The paper is divided into six parts, including the introduction. Part two review extant literature, part three highlight the theoretical framework used in the analysis, part four outlines the methodology used in the study while part five analyses the utility of regional RDC in the Burundian and Gambia conflicts. Part six concludes the study.

\section{Literature review}

The literature is reviewed on two major themes, namely regional security and rapid deployment capability and their linkages to Africa and the ASF.

Region is derived from the Latin word 'regio' which can be used both geographically and politically (Travers, 2004; Söderbaum \& Shaw, 2003) Geographically, Russett (1967) sees region as the geographical proximity, with social and cultural homogeneity, shared political attitude and institution, and economic interdependence. Similarly, Thompson (1973) refers to regions as states linked together geographically, with extensive interaction and shared perception of various phenomena. Whereas, to other scholars 'regions are politically made' and are social constructs promoted by the perception of shared communal identities of states within a location (Katzenstein, 1997, 2005). These divergent perception of the concept is rooted in it ontological disagreement. Howbeit, irrespective of the usage, region as a concept convey an idea of linkages and shared similarities between distinct locations and people within the international system which requires differentiation. Hence, effort to harmonize these differences led Travers (2004) to identify four dimensions of region, namely geography, the regularity and intensity of interaction, shared identity/perception and agency. The first dimension leans towards geographical definition, the second captures the political essence, while the third reflects the constructivist leaning of the concept which is instrumental to the formation of the fourth as a framework of common identity.

In the realm of security, regions of security are natural consequence of proximity as threats travel more easily over a short distance than longer ones (Tavares, 2010). 
However, instruments of regional security include alliances and institutions that are not restricted to membership of a restricted geographical space but also link extra regional major powers to actors within the region (Mansfield \& Solingen, 2010). This explains the emergence of the North Atlantic Treaty Organisation (NATO) and the Warsaw Pact during the Cold War era, as well as the US membership of Association of South East Asian Nations (ASEAN) which do not share common geographical location but belong to the same regional security mechanism.

Regional security, therefore, refers to collective measures sanctioned by a group of states locked up in a 'security complex' in the same geographical location or with similar socio-cultural and political affinity to counter perceived common threats to human lives and national interests in the international system. It includes various forms of collective security mechanism, security regimes, zones of relative peace, cooperative security dialogues and zones free of weapons of mass destructions (Mansfield \& Solingen, 2010).The institutionalization of these mechanisms could arise from economic interdependence or shared democratic culture, as illustrated by the EU Battlegroup and South East Europe Brigade (SEEBRIG) (Adreani,Bertran,\& Charles, 2001;Gleditsch, 2002; Mawdsley\&Quille, 2003; Simon, 2010; Tagarev, 2003;Viros, 2002). Similar mechanisms may also arise from shared interest in political and strategic realms, which justifies the formation of ECOMOG (now, ESF) and Nordic Coordinated Arrangement for Peace Support (NORDICAPS) (Essuman-Johnson, 2009; Olawale, 2015; Jeppsson, 2009; Solingen, 1998; Viros, 2002; Tagarev, 2003). Beside economic interdependence and shared democratic culture, the imperatives of transnational security communities through common understanding and perception of common threat(s) could be the foundation of the mechanisms, as illustrated by formation of the NATO Response Force (NRF) and Joint Expeditionary Force (JEF) (Adler \& Barnett, 1998; Checkel, 2005; Deutsch, Burrell, Kann, Lee, \& Lichterman, 1957; Hendriks, 2014; Molling, 2007).

In most cases, the underlying factors for the creation of regional security apparatus are reflected in the forms of cooperation and structural design, as well as the features and characteristics of the regional institutions (Solingen, 2005, 2008). Howbeit, an emergence of a regional security organization reflects the preferences and capabilities of relevance 'lead nations' (Haggard, 1997). Indeed, the formation of ECOWAS Standby Force (ESF) and SADC Standby Force (SSF) can be attributed to the preferences and capabilities of Nigeria and South Africa, while NATO Response Force (NRF) and Joint Expeditionary Force (JEF) reflect the preferences and capabilities of the US, France, and United Kingdom respectively (Essuman-Johnson, 2009; Hendriks, 2014). Thus, the preferences, capabilities and composition of dominant actors within the component states is central to the understanding of states interest in regional security arrangement as part of national security (Moravesick, 1998; Solingen, 2008). But of utmost importance is the understanding of the role of 'regional security complexes' in the formation 
of regional security mechanisms, as illustrated by the ubiquitousness of international organizations with the objective of maintaining regional peace and security, such as ANZAC Battle Group, NORDICAPS, SEEBRIG and CJEF (Buzan, 1991; Hendriks, 2014; Saxi, 2011; Tavares, 2010).

Rapid Deployment Capability (RDC), according to NATO, consist of a 'technologically advance, flexible, deployable, interoperable and sustainable force, including land, sea and air elements ready to move quickly to wherever is needed, as decided by the council' (Bialos \& Koehl, 2005, p. 1). It refers to the 'availability of national and or multinational assets (organized people/ formations, equipment and infrastructure for command and control in emergency crisis management' (Tagarev, 2003, p. 75). It involves the adaptation to warfare scenarios and the provision of immediate responses to varying battlefield contingencies. These require adequate and comprehensive preparation for unseen contingencies and possible military crisis scenarios (Yang \& Liao, 1999). In other words, it refers to the availability of a robust force with the capability for immediate deployment, mobility, flexibility and effectiveness (Langille, 2004).

According to Yang and Liao (1999), the key elements of RDC are training, speed, strength and effectiveness. Similarly, Rivlin (1983) noted that timing is critical element in the effectiveness of RDC mechanism and mobility of assets, such as airlift, sealift and prepositioning logistics and other supporting materials close to the theatre of operations which are the major determinants of effective timing. Therefore, RDC is complex and tasking even for the wealthiest and best prepared state or organization in the international system; since, prior and extensive planning is imperative. Other prerequisites include immediate availability of highly trained, well equipped personnel, and dependable transport with secure supply chain (Langille, 2014).Such force must also posses the facilities needed to sustain it operations in the conflict zone as the need arises.

The value of RDC lies on its rapidity, deploy ability, sustainability and interoperability, which distinguishes it from other conventional methods of conflict prevention (St. Pierre, 2006). It is a veritable instrument in deterring genocide or mass violence at early stage, as demonstrated by NATO intervention in Bosnia in the mid 1990s and SHIRBRIG intervention in Ethiopia and Eritrea conflict in 2001 (International Peace Academy [IPA], 2002; Zenko, 2004).

RDC within the United Nations system is subjected to internal process, as dictated by the DPKO and UNSC and externally control by the provision of national assets by member states, since the UN as an institution does not own personnel or equipments required for military operations and therefore relies on the contribution of these assets from member states. Thus, the UN has no RDC on its own but it activates such mechanism as the need arises, specifically, during crises in the international system which depends on the cooperative inter/intra organizational matrix between the DPKO, UNSC, other 
departments and member states. Consequently, the UN RDC depends on inter linkages of five levels of authority and efforts, namely: political, financial, strategic, operational and tactical. Hence, problem(s) at any level has reverberation on others and indeed the entire RDC system, and harmonious linkages of these levels and efforts lead to timely intervention in the conflict zone (Langille, 2014).

The central role of time in RDC cannot be over emphasized, as Readiness Notice (RN) is a factor which must be considered in the building of a RDC. While SHIRBRIG RN is 15-30 days (Koops \& Varwick, 2008), NRF contingent could hit RN in 5 days and Very High Readiness Joint Task Force (VJTF) with 48 hours (Hendriks, 2014); ASF has 14 days RN for war crime, genocide and crime against humanity (Kasumba \& Debrah, 2010); EU Battlegroup 10 days RN of Foreign Affairs Council (FAC) approval of the mission (Simon, 2010); UN RN, as contained in Brahimi Report, stipulates 30 days for conventional peacekeeping operations and 90 days for multidimensional model.

Indeed, the UN has the slowest RDC among the mechanisms outlined above; still, these requirements are hardly met by the Secretariat due to the reluctance of member states to commit their national assets to the UN for supranational operations. This is exacerbated by the clumsiness of the UNSC decision making in the authorization of peace support operations (Boulden \& Knight, 1995).

The import of these realities is that the UN structure and process as presently constituted suffers from insufficient political will, limited cooperation, and inadequate funding amongst others which are basic ingredients for fabrication and sustenance of $\mathrm{RDC}$ required for the management of complex emergencies in armed conflicts across the world (Langille, 2014).

In relations to Africa, the ASF was established with the goal of leveraging on the intelligence gathered from both continental and regional early warning systems to get it contingents ready for deployment to anywhere in the continent within 14 days (Kasumba \& Debrah, 2010). Problematique to RDC within the AU includes the issue of troops and other assets' ownership. Like the UN, the AU does not own troops and equipments; and therefore depends on the member states and Regional Mechanisms (RMs) for these assets, hence the RMs in each of the five designated regions serve as a general institutional pillars for the operationalization of the ASF Brigades (Warner, 2015). Achievement of Full Operational Capability (FOC) has been challenging. Relevant here, include poor logistic base, the challenge of interoperability between multinational and multidimensional components, dearth of political will, inadequate training, poor funding and lack of willingness by the AU member states to commit their troops to the ASF amongst others (Bachmann, 2011; Beza, 2015). Besides, the RDC of the ASF suffers from the deficits of buying-in from some regions; while ECOBRIG and SADCBRIG are the most prepared Brigades, FOMAC/ECCASBRIG and NARCBRIG are still struggling at infancy 
and EASBRIG falls within the two extremes, thus, the North and Central Africa's mechanisms remain the missing pillars of ASF RDC and Nigeria and South Africa serve as the hegemonic anchors for their respective regional mechanisms (Adebajo \& Landsberg 2003; Desmidt \& Volker, 2017).

The Malian crises of 2012 exposed the RDC status of the ASF, as highly deficient in spite of the political commitment the AU. Consequently, the French intervention reminded the continent of an ideal RDC required for such scenario. The development necessitated the fabrication of Africa Capacity for Immediate Response to Crisis (ACIRC) (Lotze, 2015). It was proposed as 'a transitional formula' and interim RDC mechanism to provide a 'military capacity with high reactivity to respond swiftly to emergency situations' pending the readiness of the ASF (AU, 2013; Cocodia, 2016). It is voluntary in principle and constitutes a 'coalition of the willing' states that are committed to rapid mobilization of troops and equipments for intervention in conflicts zones within the continent (DeConing, 2014). Hence, ACIRC is a 'flexible robust force made available directly by member states, on a voluntary basis to be deployed rapidly to response more effectively to emergency situations (Lotze, 2015). In terms of numerical strength, ACIRC is a brigade size mechanism, with 1500 multinational troops ready for deployment within 10 days of mandate; and capable of sustaining itself for initial 30 days (Warner, 2015). Lotze, (2015, p. 3) identifies the major differences between the ASF and ACIRC as follows:

1. Whereas, the ASF relies on member states pledging capabilities to regions, ACIRC relies on member states pledging capabilities to the AU directly, by passing regions;

2. While ASF is a multidimensional capability which can be deployed across a range of scenarios, the ACIRC is relatively smaller military force, intended to be deployed in an intervention context only; and

3. Whereas, ASF operational funding comes from non African partners, the ACIRC funding and support arrangements are largely provided by AU member states and Troops Contributing Countries.

Scholars have discussed the rationale behind the invention of ACIRC, alongside, ASF. Critics fear that ACIRC may draw attention away and undermine the investment already done in the construction of ASF (Cilliers, 2008), others observed the similarities between the two mechanisms (Cocodia, 2016), Yet, a complete dedication to the nurturing of the ASF RDC to full operational levels would be more prudent than the duplicating of efforts as seen in the ACIRC project (Fabricious, 2013; Roux, 2013). However, the difference in the composition of these mechanisms and the objectives demonstrates the complementariness expected of these arrangements. Specifically, ACIRC is mandated to mobilize only the military component and dedicated solely to military and security issues (Warner, 2015); in order to fill the yearning gap of the ASF 'Scenario Six' with 
an immediate combat, intervention based on humanitarian imperative to save lives by stopping or preventing emerging genocide, crimes against humanity, atrocities or war crimes by armed rebel force (AU, 2013; Aneme, 2008).

The real challenge of RDC in Africa is within the AU and external control, not the mechanism themselves. The continental RDC is subject to internal restrain, such as the dearth of political will and consensus by member states which slows the decision making process and indeed reaction to emergencies (Beza, 2015). Besides, the reluctance of member states to commit national assets to AU mission makes it difficult for RDC to be achieved irrespective of the mechanism which makes it akin to UNSC (Cocodia, 2016). External control centers on the inadequacy of AU PSC in terms of absolute 'legitimate mandating authority' which necessitate the continuous reference of continental issues to the UNSC authorization, or ratification of decisions in peace enforcement operations (Koops, 2009, 2012). The implication of this include bureaucratic bottleneck associated with decision making process in the Council which prolongs the deployment of the AU's RDC. Besides, the continued reliance on the EU APF for mission funding comes with additional delay, given that the EU Political and Security Committee deliberates and ascertain which mission worth funding in terms of the gravity of the threat. Thus, dearth of political will and commitment of national assets within Africa, as well as seeking of legitimacy and funding from the international system reduce the RDC within the continent.

More so, the logistic capability of African mechanism is comparatively low and this forces the AU to depend on NATO and UN for airlift of personnel and equipments, as well as supporting items to conflict zones. The deficit in heavy airlift capability and landing facilities for such carriers remains a major hindrance for speedy deployment of troops and vehicles to mission area (Kliengebiel, 2005). Also, worthy of noted is the level of professionalism in African Armed Forces, which are largely poorly trained, undisciplined and corrupt, as a result of clientelism endemic in the socio-political system in their respective countries. Again, the challenge of integration of multinational force with divergent language and culture, as well as the civilian and police components in peacekeeping generates communication difficulties and promotes division within the intervening mechanisms. This reduces the cohesiveness of the RDC, as well as the interoperability necessary for effectiveness of such intervention (Langille, 2014; Kasumba \& Debrah, 2010). Furthermore, the interface and command between the AU PSD and RMs is poorly synergized, which feeds into the delay factor and reduces the timeliness of response during emergency (Williams, 2011).

It was the need to improve the RDC of the ASF that warranted the conception of Amani Africa as a training exercise cycle, with the objective of testing and sharpening the readiness of the outfit for rapid deployment as envisioned by the AU to evaluate the 
capabilities and procedures for the engagement of the ASF in a multidimensional peace operation (Engel \& Porto, 2009). It was launched in Addis Ababa Ethiopia in 2008, where the Amani Africa I - the Command Post Exercise (CPX) took place in 2010to 'test the planning, command, control, and communication capability of AU and REC staff and the AU's decision-making process at the politico-strategic level' (Bachmann, 2011, p. 27). The second cycle: the Amani Africa II - the Field Training Exercise (FTX) took place in Lothala, South Africa in 2015 to ascertain the state of readiness of the ASF RDC with the integration of ACIRC and its Full Operational Capability (FOC) (AU, 2015; Desmidt \& Volker, 2017). In similar attempt to improve it RDC based on the lessons learnt from the deployment of the African-led International Support Mission in Mali (AFISMA), ECOWAS announced the establishment of a Special Standby Two-Battalion rapid response Force, ready to intervene within thirty days in any complex emergency within its region (AU, 2017).

In spite of efforts to improve RDC both regional and globally, critics of the use of force in conflict resolution are reserved over the deployment of mechanism with RDC for humanitarian intervention, since it involves the deployment of coercive apparatus with the inherent tendency to undermine credibility, neutrality and impartiality of the intervening mechanism (Pugh, 2004). This may be true, but the essence of such intervention must not be lost to 'just war debate' (Kamm, 2004), rather the rationality of the UN principle of Responsibility to Protect (R2P), must supersede every moral and ideological barriers, which may not save the impending human catastrophe, such as 'where a population is suffering from serious harm as a result of internal war, insurgency, repression or state failure, and the state in question is unwilling, or unable to halt or avert it' (ICISS,2001). Such extreme situations of human right violation on large scale lead to genocide, or ethnic cleansing, as experienced in Rwanda or mass killing, forced migration or systemic rape were obvious in Darfur (Hintjens, 1999; Prunier, 2005). Conflicts with such humanitarian crises cannot be resolved through impartial, creditable and neutral pacifist method, without the restoration order and stability. Such situations, therefore, require coercive intervention for the protection of non combatants, women and children, before effective conflict resolution can take place. Conventionally, RDC mechanisms are reactive coercive instrument for the containment of military crises; it isa short term measure to manage unfolding violent conflicts or 'new war' by reducing tension and violence, or possibly stop the conflict (Kaldor, 2007; United Nations, 2000). This was demonstrated by the successful deployment of ECOWAS Mission to The Gambia (ECOMIG) in January 2017 which contained the emerging conflict; and the failure of the AU to do same has led to the lingering conflict in Burundi since 2015 (Arieff, 2015; Crisis Group, 2016; Hartman, 2017; Odigie, 2017; Sanyang \& Camara, 2017; Siegle, 2015). 


\section{Theoretical Framework}

The preferred framework of analysis for this study is Collective Security. It is built on the assumption that international peace and security is the collective objective and responsibility of every nation, and all nations must work for it achievement. The idea is be traced to Immanuel Kant's Pamphlet 'Perpetual Peace', published in Koeniaberg in 1795 , which he suggested that the law of nations could be based on one federation of free states who denounce any form of offensive war against one another, but can undertake defensive wars by voluntary national army. He advocated for the 'definitive' articles of peace which include: the centrality of republican constitution for all the states; the fabrication of constitution of a Union of Nations and the construction of universal law which every individual would be consider to be a global citizen (Kleingeld, 2004). The failure of the Balance of power and subsequent the outbreak of World War I, as well as the active participation of the United States in international politics, led to the need to for inventing alternative framework for international peace and security, hence President Woodrow Wilson while condemning secret diplomacy and treaty maintained that:

Mere agreements may not make peace and security; it will be absolutely necessary that force be created as a guarantor of the permanence settlement so much greater than force of any nation now engaged, or any alliance hitherto formed or projected that no nation, no probable combination of nations could face or withstand (Aberg,197, p. 183).

Collective Security is based on the assumption that states 'form a society, membership in which confers both rights and duties, the principal right each state enjoys is the ability to maintain political independence and territorial integrity against external aggression; its principal duty is not only to refrain from aggression, but also to aid the victims of aggression (Hendrickson, 1993, p. 3). In other words, states 'agree to abide by certain norms and rules to maintain stability, and when necessary band together to stop aggression' (Kupchan \& Kupchan, 1995, p. 52). It is a framework that sees war as either an illegal act that violates the social order or an action of law enforcement that preserves the order (Hendrickson, 1993, p. 3).

It was the founding principle of the League of Nations which failed not as a result of the obsolete nature of the framework but due to the poor implementation of its provision and the withdrawal of the United States from its membership. However, the success of the United Nations in maintaining global peace and security for the past 72 years attests to the efficacy of this framework in the management of peace and security in the anarchical international system with high precision and lethal weapons unprecedented in human history. Central to its axiom is the 'unanimity of enemy' which is seen as 'a threat to regional or international peace and security'. If the system is global as the UN framework is, a threat can originate in any region, anywhere on the globe. An actor within the regional or international system that commits the aggression imperils the 
peace, or grossly exceeds the bounds of civilized behavior, violates the norms of that collective security system and is subject to enforcement action (Aleksovski, Bakreski, \& Avramovska, 2014). This provision makes it different from collective defense framework which is fabricated to counter the activities of a known, or identified potential enemy. Thus, any aggressor becomes an enemy within the collective security framework, which must be checked by the coalition of other states within the system. It is also based on two fundamental logic, namely(1) providing a balancing mechanism capable of preventing war and stopping aggression more effectively than the preceding 'balance of power', since it emphasizes deterrence and canvasses for the deployment of greater power against an aggressor and (2) the emphasis on 'one for all and all for one' (Morgenthau, 1967). These promote the creation and sustenance of peace and security through trust and cooperation, rather than competition, which has been the traditional notion of the international system (Kupchan \& Kupchan, 1991; 1995). More so, the tripartite provision of Kants Article of Peace become relevance and central to the working of Collective Security with the ascendancy of liberal democracy and perception of 'security community' (Deutsch, et al, 1957); and invention of Responsibility to Protect (R2P) by the UN which has promoted global citizenship and the protection of fundamental human rights - the core values of the AU Peace Security Architecture.

\section{Methodology}

The study adopts Case Study Research Design - which a particular instance or a few selected cases are studied intensively and analyses the interaction between the factors involve in the study (Idaka \& Anagbogu, 2012; Gilbert, 2008). The utility of this design lies on its ability to explain the nexus between regional security and RDCs across Africa. The study focuses on Burundian and the Gambian crises of 2015 and 2016/2017 respectively as the area of study, but covers issues common to the deployment of RDCs across the continent. It combines data from both primary and secondary sources. The primary data were generated from responses to open ended questions on the interview guide designed for the study and administered to scholars and diplomats with sufficient knowledge of regional security and deployment of RDCs in both conflicts under focus. Secondary data are obtained from extant literature, such as textbooks, magazines and scholarly journals. The data were presented on tables to reflect the comparative approach of the study. Content Analysis technique was used in analyzing the findings inductively.

\section{Presentation of Findings}

The overview of Burundian (2015) and The Gambian (2016/2017) Conflicts Analyses and the status of the ASF's RDC earmarked and deployed to manage the conflicts are summarized on Table 1 and Table 2 below: 


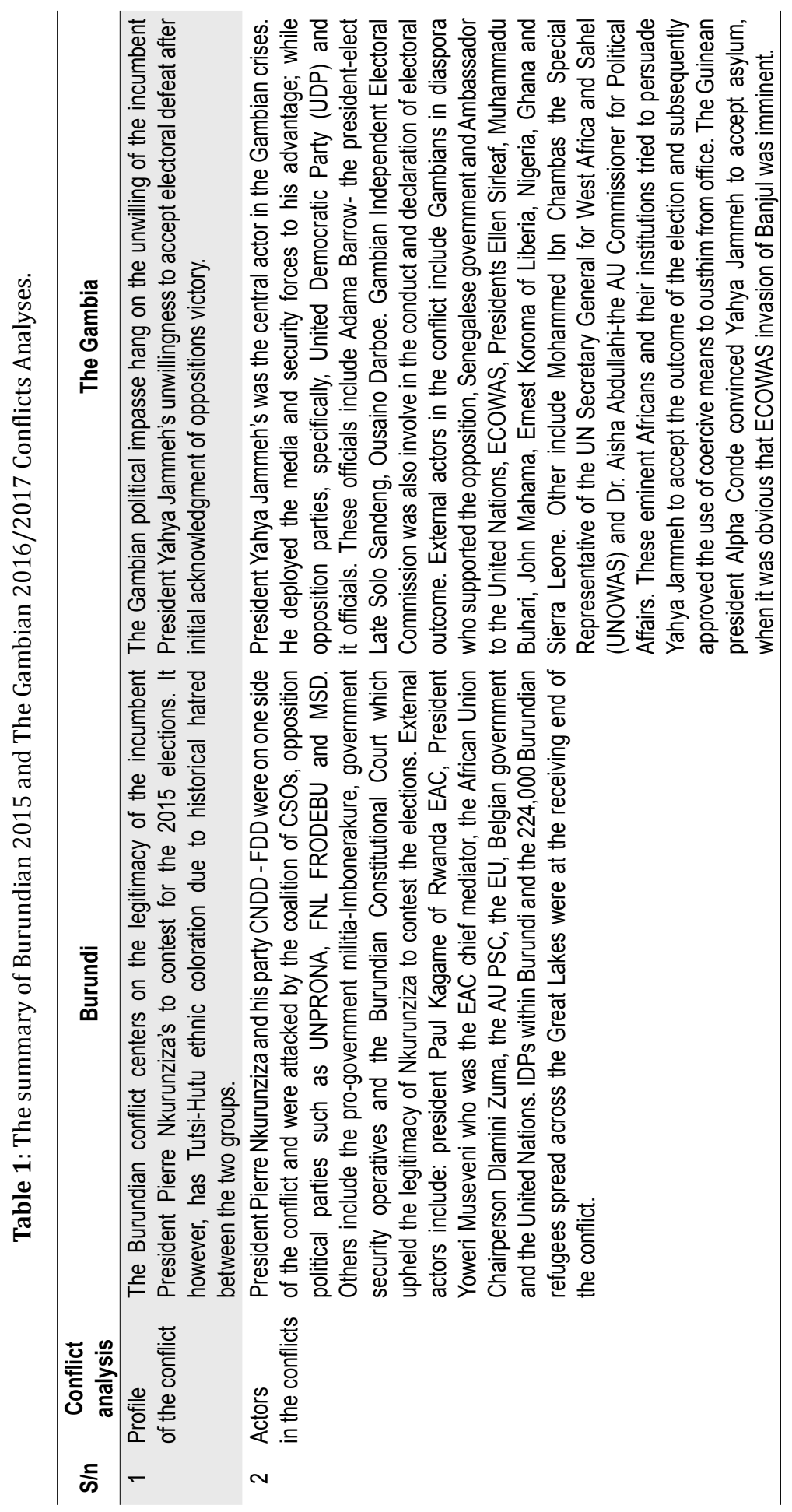




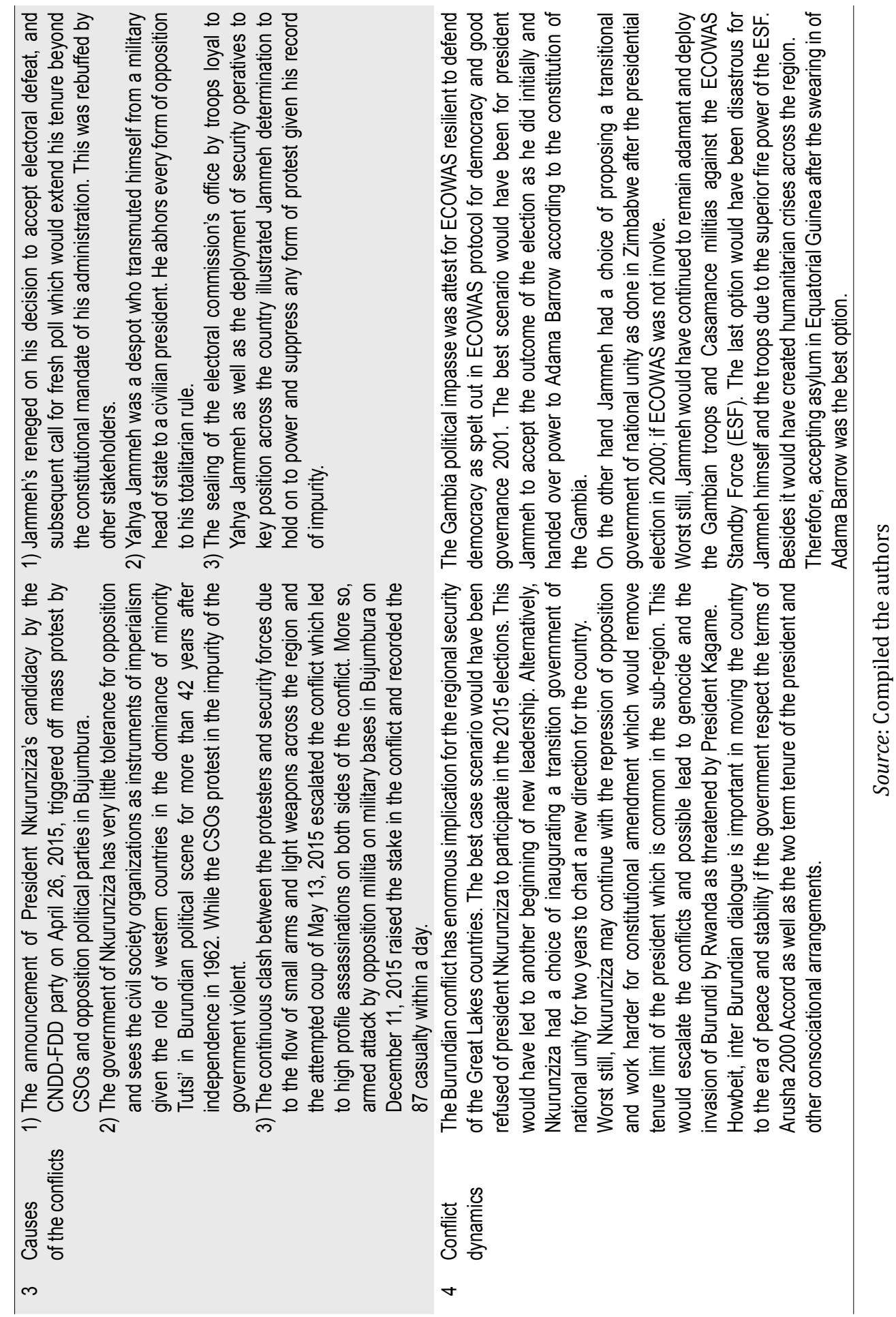




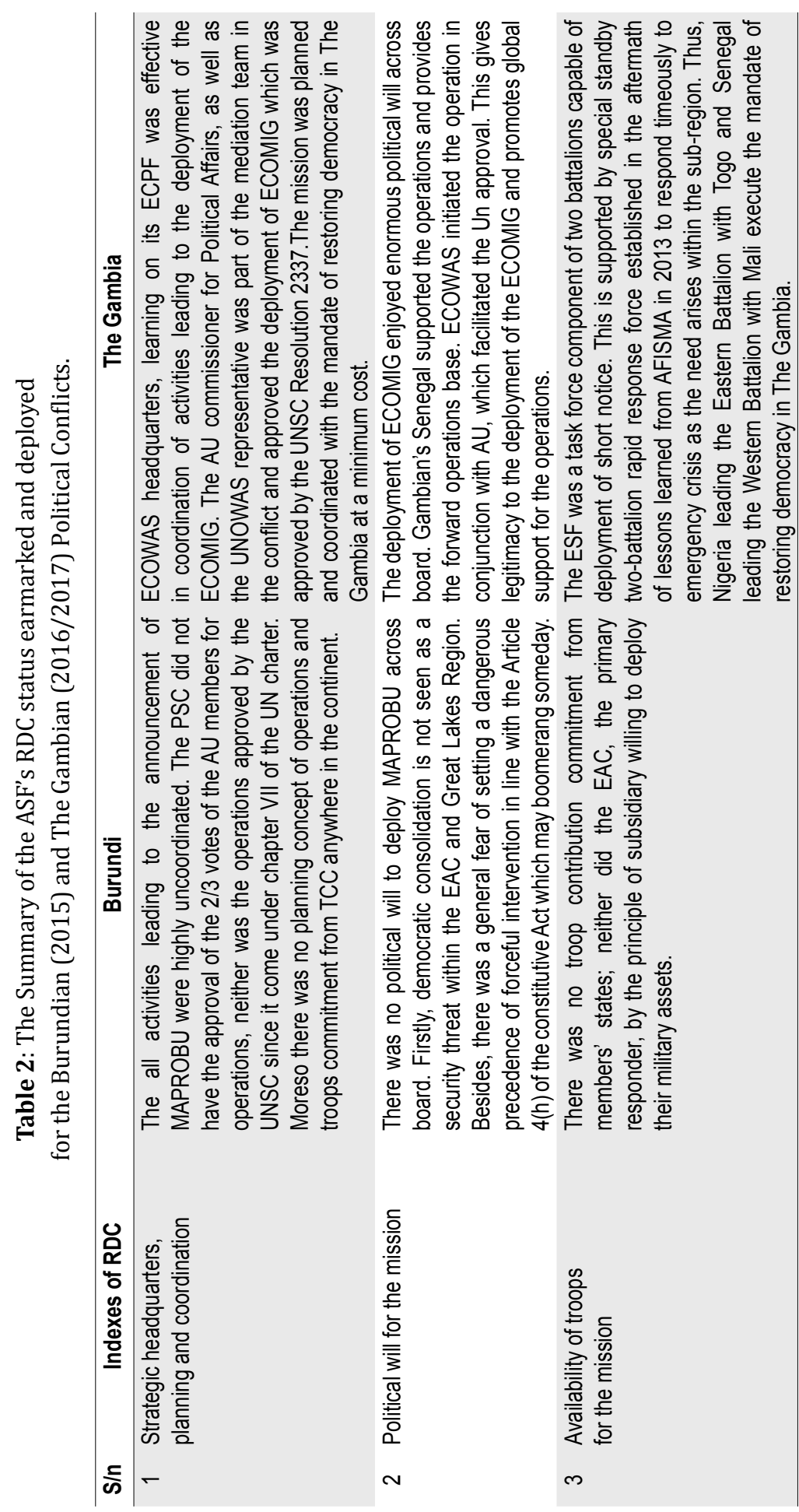




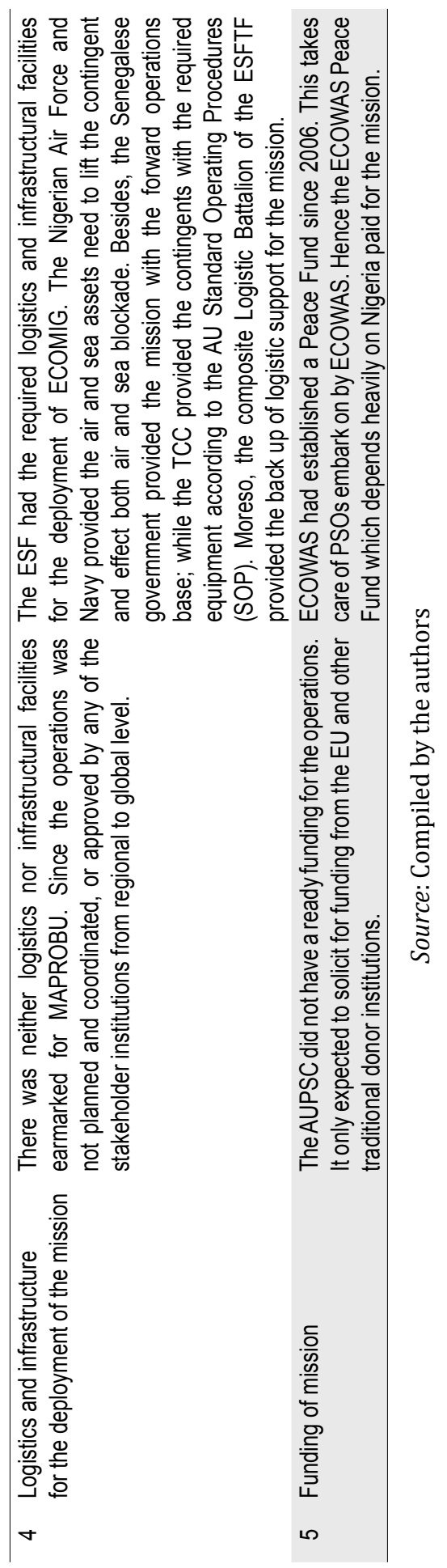




\section{Discussion of Findings}

There are elements of similarities and differences between the two conflicts under discussion. Both conflicts arose from the process of democratic consolidation. They also illustrate the culture of sit tight syndrome by African leaders and the tendency to deploy state coercive instruments against real and perceived oppositions, as well as the manipulation of state institutions for personal and regime interest. More so, in both cases, there were political repressions, abuse of the basic rights of the citizens as well as the disregard for the rule of law. Howbeit, President Nkurunziza was smarter in the exploitation of regional trend of totalitarian democracy. He manipulated institutions within the Burundi and effectively exploited the ambiguity in the constitution over his legitimacy to contest the 2015 Presidential Election. This was against the spirit of Arusha Accord of 2000 which ended the Civil War in 2005. Whereas, Yahyaammeh found himself in a precarious situation after he had decimated political opposition through death and imprisonment, as illustrated by the torture to death of Solo Sandeng and the imprisonment of Ousaino Darboe among others in the run up to the December, 2016 Presidential Elections. Jammeh unfortunately lost the election, but decided to annul it after initial acknowledgement of his defeat at the poll. Jammeh was more unfortunate since The Gambia is a signatory to the ECOWAS Conflict Preventive Framework (ECPF) which frowns at member states attempt to scuttle democratic processes. These contextual differences led to corresponding differences in the generation of the RDC needed to contain the humanitarian crises which arose from the two conflicts. With the benefit of hind sight: was regional RDC needed for intervention in Burundian and Gambian crises of 2015 and 2017?

The crisis in Burundi has enormous security impact across the countries in the Great Lakes in terms of ripples of refugee's flows, disrupted infrastructure, proliferation of weapons and exports of violence. The World Food Programme (2015) reported that about 224,000 Burundians were spread across East Africa sub-region. As at December 17,2015, the distribution shows Tanzania bears the heaviest burden of hosting more than 118,000. This was closely followed by Rwanda with about 70,000. Democratic Republic of Congo was ranked third with 19,000 refugees, while Uganda hosted about 17,000 refugees. ECHO Factsheet (2015) observes the natural distribution of the refugees and reports that $60 \%$ of all refugees were children, with a high number of unaccompanied minors in the Refugee camps across the regions. Besides, some of the camps were overcrowded and as such overstretched the available facilities which led to insufficient water supply and hygiene as well as education and health facilities. The death of 35 Burundian refugees in Tanzania in June 2015 as a result of cholera outbreak reflects the general pressure on the facilities within the refugee camps in the region. Regrettably, out of about 314 million U.S. Dollars budgeted for the protection and assistance of these refugees, only $14 \%$ of the budget was funded as at July (World Food Programme, 2015). 
Furthermore, the implication of the sudden surge in population in the host countries among others include the rising price of food and other consumable items, such pressure has the tendency to cause inflation, raise the cost of living in local communities where the refugees camps are located. More so, such influx of jobless population has the tendency to increase crime rates in the host countries with their attending cost on security management in the region.

Again, conflicts in the countries of the Great Lakes have the capacity to spill over to the neighboring countries, where colonial boundaries and policies resulted in the split of ethnic population across national boundaries. Thus, the Burundian crisis of 2015/2016 has similar signpost, the Hutus and Tutsis tension played out in the crises. Some observers feared that Rwanda's Tutsi led government could be drawn into a conflict with Burundi if one erupted (Arieff, 2015). This fear was confirmed when President Kagame threatened to intervene in Burundi, if there is an outbreak of or perceive of genocide in Burundi even without the authorization of the UN or AU (Respondent). Linked to this is the historical dynamics of conflict within the region as observes by Siegle (2015):

Africa's Great Lakes region has also been host to the most prolonged, vicious, and complicated conflicts in the continent over the past two decades. Further escalation against the population in Burundi could at any time precipitate a military intervention by neighbouring Rwanda, where memories of genocide remain fresh. This in turn, may spark a military response from other neighbours worried about Rwanda's influence in the region and recalling previous conflicts in the Democratic Republic of Congo (DRC). Likewise, there have already been reports of Rwandan Hutu rebel groups operating out of the DRC, notably the Interahamwe coming into Burundi in support of the government and aligned militias (p. 3).

Corroborating the historical dynamics of conflict in the region as experienced during the DRC conflict, Arieff (2015) noted that:

Internal conflict in DRC have long fueled regional instability and created safe heavens for Burundian combatants. Congolese territory reportedly hosts elements of the Burundian military, the Imbonerakure, and Burundian insurgent, including an FNL faction and a separate, unidentified group that reportedly entered northern Burundi in late 2014. A Rwandan origin insurgent group, the Democratic Force for the Liberation of Rwanda or FDLR which was founded by ethnic Hutus involved in the Rwanda genocide is also active in the eastern DRC. Rwandan officials allege that FDLR combatants are infiltrating Burundi amid the current crisis (p. 5).

Thus, Burundi stability is central to the regional security of the Great Lakes, as 'the conflict between Tutsi and Hutu in Burundi is at the heart of Central African regional 
instability, producing massive refugee flows, insurgencies and cross border violence (Wolphe, 2011, p. 2). Therefore, the ongoing conflict in Burundi has a wide socio-economic and politico-security implications for the region.

Similarly, Given Jammeh's impunity, the crisis in The Gambia had the potential to flood the subregion with refugees and the attended socio economic and security challenges. Human Right Watch (2016) has compiled several abuses and extra judicial killing committed by Jammeh through the security services during the April 14 -16 peaceful protests. The abuses led to massive self-exile by participants in the protest and their family members. Therefore, unchecked, Jammeh has the capacity and political will to deploy all The Gambian state coercive apparatuses to remain in power. Such development would have created humanitarian crises across the region and endanger the socio economic stability of the West Africa sub region. It was indeed clear that humanitarian crisis was looming in The Gambia, as a result of the imminent crackdown on opposition and its strong holds as reflected by the election results.

More so, a crisis ridden Gambia would increase drugs and arms trafficking into and through the region. Gambia has been identified as a major route of South American drugs trafficking to Europe and Jammeh was a facilitator in the illicit deals (Sanyang \& Camara, 2017). Besides, experiences have shown, as it was during the rumbling in the Manor River region how Small Arms and Light Weapons (SALW) were easily circulated. The impacts of those circulated SALW are still felt in the sub region. Besides, Jammeh has been part of gun running syndicate and smuggler of blood diamond during the era of Charles Taylor's war lordship in Liberia and Sierra Leone, he was also implicated in the international arms trafficking carried out by Victor Booth of Tajik Arms deal who was arrested in 2008 and extradited to the US in 2010 (Sanyang \& Camara, 2017). More importantly, Jammeh has been a major source of arms supplier to the Casamance separatist movement in Southern Senegal; many believe that he has biological affiliation to the region and only migrated into The Gambia at school age. It was also alleged that he had mobilized and armed Casamance militias to support his suppressive operations in The Gambia and possibly resist any form of foreign intervention (Respondents). Alluding to Jammeh's arms trafficking, Sanyang and Camara (2017) recalled that:

In October 2010, 13 shipping containers carrying Iranian weapons and heading towards The Gambia were impounded by the Nigerian Port Authority in Lagos. The manifest showed that the shipment came from Iran, and was addressed to Kanilai family farm, the president personal enterprise. This was not the state purchasing weapons, and there was certainly no license from The Gambian government. In his testimony to the court in Lagos, an Iranian diplomat confessed that several other shipments had already been delivered in Banjul (p. 9). 
The import of these evidences was that a desperate Jammeh was a threat to the regional security, since he had what it takes to destabilize the sub region learning from Charles Taylor's experience in Liberia.

More fundamentally, Jammeh' action was a test for the ECOWAS on the protection and preservation of democratic values and the commitment of the sub regional body to the values. As highlighted earlier on in the study the regional security complex in the sub region arises majorly from democratic deficit orchestrated by dictatorial tendency and 'sit tight leadership syndrome' which led to the rumbling in the manor region towards the close of last century. In order to check the recurrence of the crisis, the regional leadership revised the ECOWAS Treaty in 1993 and gave premium to preventive conflict resolution strategies and frown at any form of unconstitutional governance and change of government. This led to the ratification of the protocol on the Mechanism for Conflict Prevention (1999) and the Protocol on Democracy and Good Governance (2001) by member states in order to check the inherent security threat associated with the institutionalization of democracy through the ballot box. These two instruments constitute the ECOWAS Conflict Preventive Framework (ECPF) and reinforce each another (Atuobi, 2010; Ekiyor, 2008; Lewis, 2014). Hence, overlooking Jammeh recalcitrance would set a bad precedence and contradicts the wordings and spirits of the ECPF (Hartman, 2017; Odigie, 2017; Sanyang \& Camara, 2017). Thus, both conflicts required regional RDC to contain these threats to security.

Given the utility of regional RDC to the conflicts: what was responsible for disparity in generating regional RDC in the Burundi and Gambia crises? Evidences from the studies of Burundi and The Gambia show that the AU was actively involved in the process of detection the threat and their analyses, but there was a gap in the Burundian case. While the AU defined the threat and proffer solution based on the personal assessment of the AU Chairperson, the EAC perceived the Burundian crisis as a political contest which could be resolved without resorting to the deployment of a RDC mechanism. This difference led to the stalemate on troop generation and deployment. In the case of The Gambia, ECOWAS and the AU had the same definition of the problem and conception of solution based on the same principle of subsidiary, complementary and comparative advantage, the AU allowed ECOWAS to take the lead as the primary responder. This led to effective collaboration and co-ordination between the organizations and ease the process of co-opting the UN to buy into the common solution reached by both the ECOWAS and the AU. This resulted in the successful planning, coordination and deployment of the ECOMIG. Unfortunately, for the AU PSC, the violence in Burundi had declined weeks after its ultimatum to the Burundi government which reduced the credibility of deploying RDC mechanism by the end of January 2016 when the AU summit took place (Crisis Group, 2016). 
More so, the study reveals that most African Heads of State are rhetorically committed to the ideals of the African Peace and Security Architecture (APSA) and indeed the ASF. Most of them are afraid of giving blanket commitment to ASF intervention in crisis in the continent due to their personal and regime interest. The fear is reinforced by the nature of crises in the continent which are caused by democratic deficit. Hence, sitting presidents are reluctant to support the use of force by the ASF to resolve crisis arising for sit-tight leadership and demand for competitive elections. These were illustrated in the case studies in focus. The EAC was not committed to the use of the ASF to resolve the Burundian crisis in spite of heavy casualty and the evidence of looming humanitarian and security disaster caused by the refugee and arms flow. They were more interested in not setting a precedence that would boomerang given their poor democratic credentials. Besides, both Jamneh and Nkuranziza rejected ASF intervention for personal and regime interest in order to maintain their grip on power at the expense of commitment to the AU ideals of protecting and preserving the lives of Africans through the principle of 'indifference' to atrocities against it citizens.

Furthermore, the study reveals the importance of principles and values in mobilizing RDC for PSOs. The case studies again illustrate the centrality of common norms in generating consensus and political will in resolving conflict and deploying RDC mechanism in the continent. The ratification of the ECOWAS Protocol on Democracy and Good Governance which is part of the ECOWAS Conflict Preventive Framework (ECPF) by member states was instrumental to collective definition and perception of the threat of Jammeh's action. It also provided the legal platform to legitimized all the measures adopted by ECOWAS, including the deployment of the ESF. This confirms the role of democracy in building a 'security community' and the "democratic peace", hence ECOWAS can be seen as a democratic security community capable of generating the needed political will in resolution of conflict within it domain. Whereas, the paucity of common normative framework in other work part of the continent accounts for the poor political will given to the AU/PSC in resolving conflict relating to democracy by force as illustrated the Burundi case study.

\section{Conclusion}

The study has affirmed the utility of collective security mechanism with a RDC in containing violence and potential violent conflicts as envisaged by the founding fathers of the UN and the AU. The successful resolution of The Gambian 2016/2017 impasse created by the recalcitrant former President Jammeh illustrates the usefulness of a RDC in Africa. Similarly, the lingering crisis in Burundi can be attributed to the failure of the $\mathrm{AU}$ and the EAC to intervene coercively even when the casualty figure was higher than in The Gambia and the regional security situation in the Great Lakes is more volatile than in West Africa. The resemblance of peace in Burundi should not be taken for granted 
due to the inherent deficiency in democratic norms and values. This is exacerbated by ethnic suspicion between the Hutus and Tutsis. The post elections violence seems to have abated, but could erupt more tumultuously in 2019 when the preparation for 2020 Presidential Elections begins, since the incumbent may decide to tinker with the constitution and remove presidential term limit which is very common in East and Central Africa. Hence, the failure of African leaders to create a competitive democratic community is the greatest security threat in Africa; since a competitive democratic community in West Africa has provided a comprehensive mechanism for conflict prevention and resolution which could be adopted by other regional blocks in the continent, as it was effective in dealing with Gambia conflict. Although competitive democracy with two terms limit does not provide solution to all societal problems; it facilitates peaceful change of government and enhances the generation of political will in regional organizations for the deployment of a RDC mechanism in defense of democratic ideals. This is important since democratic deficit is at the root of most conflicts in the continent. It is therefore recommended that the moribund African Governance Architecture (AGA) should be reviewed and ratified by African leaders, if they are indeed committed to the regional security beyond ceremonial rhetoric.

\section{References}

1. Aberg, S. (1971). Woodrow Wilson and the League of Nations: why was a just cause defeated. New York: Scholastic.

2. Adebajo, A., \& Landsberg, C. (2003). South Africa and Nigeria as hegemons. In M. Baregu and C. Landsberg (Eds.), From Cape to Congo: Southern Africa's evolving security challenges (pp. 171-203). Boulder: Lynne Rienner.

3. Adler, E., \& Barnett, M. (1998). Security communities. New York: Cambridge University Press.

4. Adreani, G., Bertran, C., \& Charles, G. (2001). Europe's military revolution. London: Centre for European Reforms.

5. African Union. (2002).Protocol relating to the establishment of peace and security council of the African Union. Addis Ababa: African Union Secretariat.

6. African Union. (2013, April 30). Report of the Chairperson of the Commission on the operationalisation of the Rapid Deployment Capability of the African Stand-by Force and the establishment of an "African Capacity for Immediate Response to Crisis". Addis Ababa: African Union.

7. African Union. (2015). Press release: Amani Africa II Final Preparation Conference concludes in South Africa. Addis Ababa: Africa Union.

8. African Union. (2017). The African Standby Force: Draft Maputo strategic workplan (2016-2020) Addis Ababa: African Union.

9. Aleksovski, S., Bakreski, O., \& Avramovska, B. (2014). Collective security - The role of international organizations - Implications in international security order. Meditererean Journal of Social Science, 5(27), 271-283. 
10. Ali, W. (2012). The role of Nigeria in regional security policy. Abuja: Fredrich Ebert Stiftung.

11. Aneme, G. (2008). The African Standby Force: Major issuesunder 'Mission Scenario Six'. Journal of Political Perspectives, 2(1), 1-22.

12. Arieff, A. (2015). Burundi's electoral crisis: In Brief. Washington DC: Congressional Research Service.

13. Atuobi, S. (2010). Implementing the ECOWAS Conflict Prevention Framework: Prospects and challenges. Policy Brief 3/2010. Accra: Kofi Annan International Peace Keeping Training Centre.

14. Bachmann, 0. (2011). The African Standby Force: External support to an "African Solution to African Problems". IDS Research Report No. 67. Brighton: Institute of Development Studies.

15. Bah, A. S., Choge-Nyangoro, E., Dersso, S., Mofya, B., \& Murithi, T. (2014). The African Peace and Security Architecture, A handbook. Addis Ababa: Friedrich Ebert Stiftung.

16. Beza, Y. (2015). The African solution to African problems: Challenges of African Standby Force (ASF). Journal of Social Sciences and Humanities, 1(4), 450-467.

17. Bialos, J., \& Koehl, S. (2005). Facilitating coalition warfare through technology transfer and information sharing. Washington DC: Centre for Technology Transfer and National Security Policy - National Defence University.

18. Boulden, J., \& Knight, W. (1995). Rapid reaction: Filling the gap. In D. Cox and A. Legault (Eds), UN Rapid Capabilities: Requirements and prospects (pp. 36-48). Clementsport: Canadian Peacekeeping Press.

19. Buzan, B, (1991). People, states and fear: An agenda for international security studies in the post-Cold War era. New York: Harvester Wheatsheaf.

20. Checha, B. (2004). From conflicts to global terrorism. African Journal of International Affairs, 7(3), 59-69.

21. Checkel, J. (Ed.). (2005). International institutions and socialization in Europe. International Organisation, 59(Special Issues), 801-1079.

22. Cilliers, J. (2008). The African Standby Force: An update in progress. Pretoria: Institute for Security Studies.

23. Cleaver, G., \& Massey, S. (2001). DRC Africans scramble for Africa. In O. Fowley and R. May (Eds.), African interventionists states (pp. 193-210). Aldershot: Ashgate.

24. Cocodia, J. (2016). The African Capacity for Immediate Response to Conflict and the African Standby Force: Options for peace intervention in Africa. Social Science Council Research Working Papers: African Peacebuilding Network, APN Working Paper: No 7.

25. Crisis Group. (2016). The African Union and the Burundian Crisis: Ambition vs reality. Nairobi/Brussels: International Crisis Group.

26. De Coning, C. (2014). Enhancing the efficiency of the African Standby Force: the case for a Shift to a Just-in-Time Rapid Response model? Durban: The African Centre for the Constructive Resolution of Disputes.

27. Desmidt, S., \& Volker, H. (2017). Conflict management under the African Peace and Security Architecture (APSA): An analysis of conflict prevention and conflict intervention 
by African Union and Regional Economic Communities in violent conflicts in Africa for the Years 2013 - 2015. ECDPM Discussion Paper, No 211, April. Retrieved from http:// ecdpm.org/publications/conflict-management-under-the-apsa/.

28. Deutsch, K., Burrell, S., Kann, R., Lee, M., \& Lichterman, M. (1957). Political community and the North Atlantic area: International organisation in the light of historical experience. Princeton, NJ: Princeton University Press.

29. Dorn, W. (1998). Regional peacekeeping is not the way out. Peacekeeping and International Relations, 27(3\&4).

30. ECHO Factsheet (2015). Burundi refugee crisis. Brussels: European Commission Humanitarian and Aid and Protection.

31. Ekiyor, T. (2008). ECOWAS Conflict Prevention Framework (ECPF): A new approach to old challenges. Accra: West Africa Civil Society Institute.

32. Engel, U., \& Porto, J. (2009). The African Union's new peace and security architecture: Toward an evolving security regime? African Security, 2(2-3), 82-96.

33. Essuman-Johnson, A. (2009). Regional conflict resolution mechanisms: A comparative analysis of two Africa security complexes. African Journal of Political Science and International Relations, 3(10), 401-422.

34. Fabricious, P. (2013, November 7). Does the unwieldly label of the African Capacity for Immediate Response to crises conceal a real determination to act? ISS Today. Retrieved from https://issafrica.org/iss-today/does-the-unwieldy-label-of-the-african-capacityfor-immediate-response-to-crisis-conceal-a-real-determination-to-act.

35. Fearon, J., \& Laitin, D. (2003). Ethnicity, insurgency, and civil war. The American Political Science Review, 97(1), 75-90.

36. Franke, B. (2006). In defense of regional peace operations in Africa. Journal of Humanitarian Assistance, 185, 136-148.

37. Gilbert, N. (2008). Researching social life (Third Edition). London: Sage.

38. Gleditsch, K. (2002). All international politics is local: The diffusion of conflict, integration, and democratization. Ann Arbor: University Michigan Press.

39. Greenhill, K. (2001) Mission impossible? Preventing deadly conflict in the African Great Lakes Region. Security Studies,11(1), 77-124.

40. Haggard, S. (1997). Regionalism in Asia and the Americas. In E. Mansfield and H. Milner (Eds.), The Political economy of regionalism (pp. 20-49). New York: Columbia University Press.

41. Hartman, C. (2017). ECOWAS and the restoration of democracy in The Gambia. Africa Spectrum, 52(1), 85 - 99.

42. Helman, G., \& Ratner, R. (1993). Saving failed states. Foreign Policy, 89, 3-20.

43. Hendrickson, D. (1993). The ethics of collective security. Ethics and International Affairs, 7, 1-15.

44. Hendriks, R. (2014). Response force galore; A guided tour. Cligendael Policy Brief. Hague: Netherlands Institute of International Relations.

45. Hintjens, H. (1999). Explaining the 1994 genocide in Rwanda. The Journal of Modern African Studies, 37(2), 241-286. 
46. Human Right Watch. (2016). More fear than fair: Gambia's 2016 Presidential Election. New York: Human Right Watch.

47. ICISS. (2001). The Responsibility to Protect: Report of the Commission on Intervention and State Sovereignty. Ottawa: International Development Research Centre.

48. Idaka, I., \& Anagbogu, G. (2012). Research Design. In A. Isangedighi (Ed.), Essentials of Research and Statistics in Education and Social Science (pp. 64-77). Calabar: EtiNwa Associates.

49. International Peace Academy. (2002). International Peace Academy seminar on Standby High Readiness Brigade (SHIRBRIG).New York: International Peace Academy.

50. Jeppsson, T. (2009).Sweden military transformation and the Nordic Battle Group - for what and towards what? KunglKrigsvetenskapsakademiensHandlingarOchTidskrift. Diskussion and Debatt 05.

51. Kaitera, J., \& Ben-Ari, G. (2008). EU Battlegroup and NATO Response Force: A marriage of convenience? Euro focus. Washington DC: Centre for Strategic and International Studies.

52. Kaldor, M. (2007). The new and old wars. California: Stanford University Press.

53. Kalyvas, S. (2001). "New" and "Old" civil wars: A valid distinction? World Politics, 54(1), 99-118.

54. Kamm, F. (2004). Failures of just war theory: Terror, harm and justice. Ethics, 1(4), 650692.

55. Kasumba, Y., \& Debrah, C. (2010). An overview of African Standby Force. In C. de Coning and Y. Kasumba (Eds.), The civilian dimension of the African Standby Force (pp. 10-19). Addis Ababa: African Union.

56. Katzenstein, P. (1997). Introduction: Asian regionalism in comparative perspective. Ithaca, New York: Cornell University Press.

57. Katzenstein, P. (2005). A world of regions: Asia and Europe in the Americani imperium. Ithaca, New York: Cornell University Press.

58. Kleingeld, P. (2004). Approaching Perpetual peace: Kant defence of a league of states and his ideal of a world federation. European Journal of philosophy, 12(93), $304-325$.

59. Kliengebiel, S. (2005). How much weight for military capabilities? Africa's new peace and security architecture and the role of external actor. Bonn: Deutsches Institut fur Entwicklungspolitiks.

60. Knight, W. (1996). Developing a Rapid Reaction Capability for the United Nations, Ralph Bunche Institute on the United Nations. Columbia International Affairs Online. Retrieved from http://www.ciaonet.org/wps/kna01/.

61. Koops, J. (2009). Effective inter- organisationalism? Lessons learnt from Standby High Readiness Brigade (SHIRBRIG). In J. Koops (Ed.), Military Crises management: The challenges of Inter-organisationalism. Studia Diplomatica, LXII(3), 81-89.

62. Koops, J. (2012). Peace operations partnership; assessing cooperation mechanisms between secretariats. Berlin: Centre for International Peace Operations.

63. Koops, J., \& Varwick, J. (2008). Ten Years of SHIRBRIG - Lessons Learned, Development Prospects and Strategic opportunities for Germany. GPPI Research Paper Series No 11. Berlin: Global Public Policy Institute. 
64. Kupchan, C., \& Kupchan, C. (1991). Concerts, collective Security and the future of Europe. International Security, 16(1), 114-161.

65. Kupchan, C., \& Kupchan, C. (1995). The promise of collective security. International Security, 21(4), $241-277$.

66. Langille, P. (2004). Bridging the commitment - capacity gap: A review of the existing arrangements and options for enhancing UN Rapid Deployment. New Jersey: The Center for United Nations Reform Education.

67. Langille, P. (2014). Improving United Nations Capacity for Rapid Deployment. New York: International Peace Initiative.

68. Lewis, R. (2014). Conflict prevention in West Africa: Understanding institutional approach for integration of preventive measures in the ECOWAS Conflict Prevention Framework. A paper presented at the $10^{\text {th }}$ Biennial Graduate Conference, University of Massachusetts, Boston, October 31 - November 1.

69. Lotze, W. (2015). The future of African peace operations: Time to adjust the operational design. Berlin: Zif Centre for International Peace Operations.

70. Mansfield, E., \& Solingen, E. (2010). Regionalism. Annual Review of Political Science, 13, 145-163. DOI: 10.1146/annurev.polisci.13.050807.161356.

71. Mawdsley, J., \& Quille, G. (2003). Equipping the rapid reaction force: Options for and constraints on a European defence equipment strategy. Bonn: Bonn International Center for Conversion.

72. Mengisteab, K. (2011). Critical factors in the Horn of Africa's raging conflict. Uppsala Discussion Paper 67. Uppsala: Nordiska Afrikainstitutet.

73. Molling, C. (2007). NATO and EU rapid response: Contradicting or complimentary? CSS Analyses in Security Policy, 2(22), 1-3.

74. Moravesick, A. (1998). The choice for Europe: Social purpose and state power from Messina to Maastricht. Ithaca, New York: Cornell University Press.

75. Morgenthau, H. (1967). Politics among nations. New York: Knopf.

76. Newman, E. (2004). The "New Wars" debate: A historical perspective is needed. Security Dialogue, 35(2), 173-189.

77. Odigie, B. (2017). In defence of democracy: Lessons from ECOWAS management of The Gambia 2016 post - election impasse. ACCORD Policy and Practice Brief No 46. Durban: The African Centre for the Constructive Resolution of Disputes.

78. Okoro, J. (2002). Understanding Nigerian foreign policy. Calabar: Cats Publishers.

79. Olawale, I. (2015). Towards a community of practice: ECOWAS and peace and security policy in West Africa. New York: Social Science Research Council.

80. Prunier, G. (1995). The Rwanda crisis 1959-1994: History of genocide. Kampala: Fountain Publishers.

81. Prunier, G. (2005). Darfur: the ambiguous genocide. Ithaca: Cornel University Press.

82. Pugh, M. (2004). Maintaining peace and security. In D. Held and A. McGraw (Eds.), Governing, Globalisation, Power, Authority and Global Governance (pp. 217-225). Cambridge: Blackwell. 
83. Reid, R. (2014). Horror, hubris and humanity: The international engagement with Africa, 1914-2014. International Affairs, 90(1), 143-165.

84. Rivlin, A. (1983). Rapid Deployment Force: Policy and budgetary implication. Washington DC: United States Congressional Budget Office.

85. Roux, A. (2013, June 14). New super combat brigade: Creation of African elite? ISS Africa Today. Retrieved from https://issafrica.org/iss-today/new-super-combat-brigadecreation-of-an-african-elite.

86. Russett, B. (1967). International regions and international systems. Chicago: Rand-McNally.

87. Sanyang, E., \& Camara, S. (2017). The Gambia after election: Implications for governance and security in West Africa. Dakar: Friedrich Ebert Stiftung.

88. Saxi, H. (2011). Nordic defence cooperation after the Cold War. Oslo: Norwegian Institute for Defence Studies.

89. Siegle, J. (2015). The political and security crisis in Burundi. A Testimony to the United States Senate Foreign Relations Sub-Committee on Africa and Global Health Policy, December 9.

90. Simon, L. (2010). Command and control? Planning for EU military operations. Paris: European Union Institute for Security Studies.

91. Söderbaum, F., \& Shaw, T. (2003). Theories of new regionalism: A Palgrave Reader. Houndmills and New York: Palgrave Macmillan.

92. Solingen, E. (1998). Regional orders at century's dawn: global and domestic influences on grand strategy. Princeton NJ: Princeton University Press.

93. Solingen, E. (2005). East Asian regional institutions: characteristics, sources, distinctiveness. In T. Pempel (Ed.), Remapping Asia: Competing Patterns of Regional Integration (pp. 31-53). Ithaca, NY: Cornell University Press.

94. Solingen, E. (2008). The genesis, design, and effects of regional institutions: lessons from East Asia and the Middle East. International Studies Quarterly, 52, 261-294.

95. St. Pierre, K. (2006). The role of rapid reaction force: Predicating responsibility in cases of humanitarian crises. Ottawa: Centre for Security and Defence Studies.

96. Tagarev, T. (2003). Developing South East European cooperative crisis management capacity. Information and Security. An International Journal, 10, 72-83.

97. Tatschl, C. (2009). SHIRBRIG's support to the African Standby Force: A view from practice. In J. Koops (Ed.), Military Crises Management: The challenges of Inter-organisationalism. Studia Diplomatica, LXII(3), 91-97.

98. Tavares, R. (2010). Regional security: the capability of international organisations. London: Routledge.

99. Thompson, W. (1973). The regional subsystem: a conceptual explication and propositional inventory. International Studies Quarterly, 17, 89-117

100. Travers, R. (2004). The state of the art of regionalism: The past, present and future of a discipline. Gothenburg: Peace and Development Research, Gothenburg University.

101. United Nations (2000). Report of the panel on United Nations Peace Operations, A/55/305-S/2000/809. New York: United Nations. 
102.Viros, T. (2002). Sub regional cooperation in South Eastern Europe. AARMS, 1(2), 283297.

103. Warner, J. (2015). Complements or competitors? The African Standby Force, the African Capacity for Immediate Response to Crises, and the future of rapid reaction force in Africa. African Security, 8, 56-73.

104. Williams, P. (2011). War and conflict in Africa. Cambridge: Polity Press.

105. Wolphe, H. (2011). Making peace after genocide: Anatomy of the Burundi process. Washington DC: United States Institute for Peace.

106. World Food Programme. (2015). Burundi crisis - Regional impact. Situation Report No 13. Rome: World Food Programme.

107. Yang, A., \& Liao, M. (1999). PLA rapid reaction forces: Concepts, training, and preliminary assessment. In J. Mulvernon and R. Yang (Eds.), The People Liberation Army in the Information Age (pp. 48-57). Santa Monica CA: RAND Corporation.

108.Zenko, M. (2004). Saving lives with speed: Using rapidly deployable forces for genocide prevention. Defence and Security Analysis, 20(1), 3-19. 